Herrera is doing in Mexico and referred to some of the difficult problems which he encounters.

Mr. Felt presented a paper as follows:

\title{
OBSERVATIONS ON THE BIOLOGY AND FOOD HABITS OF THE CECIDOMYIIDAE
}

By E. P. Felt, Albany, N. $Y$.

The species belonging to this family, though small and easily distinguished from most other Diptera, are exceedingly abundant and subsist in the larval stage under quite varied conditions. The majority of forms live upon plants and a goodly proportion produce galls. These peculiar structures occur upon the roots, root stalks or underground buds, along the stem, on the branches, on the leaves or even among the flowers or flower heads as the case may be. One genus for example, Rhopalomyia, attacks all parts of various Solidagos, except perhaps the root, the galls being quite varied in character and the adults from the same representing distinct species and, so far as known to us, coming only from galls possessing certain characters. On the other hand, Asphondylia monacha O. S., a most striking form, occurs not only in terminal rosette galls on the narrow-leaved Solidago, Euthamia lanceolata and E. graminifolia, but may breed in apparently unaffected florets of the same plant or may be found in what we have designated as adherent galls on Solidago canadensis and S. serotina. These latter structures are inhabited by two species belonging to as many genera and appear to be produced by the female laying eggs between the closely apposed young leaves in the rapidly growing bud. The larvæ cause a depression on each surface and the margins adhere, so that when the plant develops and the leaves turn down, the pair affected adhere at the point of injury though their bases are an inch or more apart. The form of the gall appears to be determined largely by the location and number of eggs the female deposits; for example, the midrib deformity on ash leaves, known as the gall of Cecidomyia pellex, may range in length from about $1 / 2$ to $2 \frac{1}{2}$ inches. It appears to develop directly as a result of the larval irritation on the upper surface of the midrib; the size of the gall being proportionate to the number of larvæ, small ones having perhaps five or six, while the largest may have as many as 50 to 60 . Certain species breed in more or less regularly rolled leaves, and in this case there seems to be a comparatively slight irritation and the form of the roll is governed mostly by the location of the larvæ and the structure of the leaf. Other species subsist in more or less irregular depressions, and here again the irritation is comparatively slight. There is one form, for example, which produces a slightly depressed rectangular area on the 
underside of milk-weed leaves. The boundaries of the deformity are evidently limited by the stout reticulating veins characteristic of this plant. The circular ocellate gall on hard maple, known as Cecidomyia ocellaris, is presumably produced in the same way, and its form is governed by ordinary mechanical laws, as there are few rigid veins to modify its margin. The form of irregular subcortical galls on various shrubs and certain herbaceous plants appears to be determined very largely by the degree of infestation, and this is presumably limited by the egg-laying habits of the female. There are, in addition to the gall-making species, a number of forms which may breed in decaying "wood, in other rotting vegetable matter, or subsist upon fungus or even prey upon other species such as Aphids and Acarids.

The duration of the life cycle varies greatly between the different groups, and in some cases, apparently among members of the same group. It is presumable that most of the Lasiopterines and the somewhat nearly related Rhabdophagas and their allies produce but one generation annually. The same is probably true of most of the Asphondylines and presumably of numerous representatives among the higher groups, including such well known species as the pear midge, Contarinia pyrivora, and the introduced European Contarinia rumicis, which breeds in the seeds of Rumex crispus. On the other hand, certain species like the Hessian fly, Mayetiola destructor Say and the violet gall midge, known as Contarinia violicola, complete the life cycle within a relatively few weeks, and the number of generations is governed almost entirely by climatic conditions and the presence of a supply of suitable food. A large number of our species winter within their galls in the larval stage. This is true of all Lasiopterines known to us which occur in subcortical galls, in stem galls and in at least certain of the blister galls. It is also the case with certain Hormomyias producing leaf galls on hickory. Others forsake the gall and winter in subterranean cells, possibly under vegetable debris and frequently in well-developed cells.

There are some exceedingly interesting correlations existing between these forms and their food habits. Among the Lasiopterines, for example, the genus Clinorhyncha, represented in this country by at least one introduced European species (C. millefolii Wachtl.) appears to breed entirely among the florets of certain compositae such as yarrow, tansy and the common daisy. Another genus, provisionally referred to Baldratia Kieff., breeds in very large measure in the peculiar, apparently fungous affected blister galls so abundant on solidago and aster, though at least one form has been reared from an apparently unaffected leaf of Erigeron. Larvæ belonging to Lasioptera occur largely in subcortical galls on the stems or branches 
of certain shrubs and herbaceous plants, there usually being a number of larvæ in each gall. The botanical genera, Solidago and Aster, appear to be prime favorites with this group of insects. The willows, Salix species, have a peculiar fauna, and it is worthy of note that, so far as known to us, not a Lasiopterine has been reared from an American Salix, though a species of Clinorhyncha was taken on this plant. This is the more remarkable, as they occur abundantly in subcortical galls on a number of shrubs and trees such as Sambucus, Viburnum, Lindera, etc. The genus Salix appears to be a prime favorite with Cecidomyiidæ referable to Rhabdophaga or nearly allied genera. These insects produce varied subcortical galls on stems and branches, and are also responsible for several bud galls. The poplar, Populus species, differs markedly from Salix in its Cecidomyiid fauna. A European species of Lasioptera has been reared from this genus, while in America we have obtained but one species of Rhabdophaga, as contrasted with some ten or more bred from Salix. We have bred, presumably from poplar, a representative of the aberrant genus Oligarces. There are, in addition, a number of leaf galls occurring on poplar, upon which we are not prepared to report. Many representatives of the genus Dasyneura and its allies subsist in loose bud galls or folded leaves such, for example, as Dasyneura leguminicola Lintn., which breeds in clover heads, the European D. trifolii F. Lw. in the folded leaves of clover, and $D$. pseudacacice Fitch in the folded leaves of black locust. The larvæ of Dasyneura flavotibialis Felt subsist in fungous affected, rotting wood. Oligotrophus asplenifolia Felt was reared from the folded leaves of sweet fern, Comptonia asplenifolia, while several species of Rhopalomyia occur in large numbers in compound terminal heads of Solidago. Certain species of Hormomyia breed in some of the well known hickory leaf galls, while the larva of H. crataegifolia lives in a leaf fold on Crataegus. Some European species of this genus have been reared from galls in grass stems, and undoubtedly certain of our American forms have similar habits. Many members of the Diplosid group occur in folded leaves, loose tip galls or even in more or less abnormal florets.

Some of the incident perplexities of this work are illustrated by our having reared four species of Diplosids from florets of the spreading Dogbane, Apocynum androsaemifolium. A rather irregular, loose leaf fold gall on the base of hazel leaves may produce three or four species, while we have obtained two distinct forms from the rather well known tumid leaf gall on grape, ascribed to Lasioptera vitis $\mathrm{O}$. $\mathrm{S}$. There is, in addition, a petiole gall on grape which has produced three forms referable to as many genera, while the common horseweed, Erigeron, normally produces two entirely different species. 
It is impossible to state at the outset just what material may or may not produce Cecidomyiidæ, since we have bred a species of Lasioptera from an apparently normal Diervilla stem only $1 / 8$ of an inch in diameter.

Afternoon Session, Friday, December 2\%, $190 \%$.

The session was called to order at $1 \mathrm{p}$. m. and the presidential address was discussed.

Mr. J. B. Smith stated that he considered the address very timely. He believed, however, that owing to the recent extension of the field of the economic entomologist that there is danger that he may unconsciously get out of his proper field of work. In insecticide investigations the entomologist should secure the coöperation of the chemist. $\mathrm{He}$ is satisfied that the diseases of the brown-tail and gypsy moths had destroyed more of the insects than the parasites, but in this field the work of the plant pathologist is needed. Certain cranberry insects have modified the entire plan of cranberry culture, while in the mosquito campaign in New Jersey, where about 15,000 acres of salt marsh have been drained by the construction of over 2,200,000 feet of ditches, the problem has become one of engineering to a large extent. $\mathrm{He}$ believed that when we get outside the range of entomology, experts in the allied sciences should be consulted.

Several other members expressed their appreciation of the address.

Mr. Newell presented the following paper:

\section{NOTES ON THE HABITS OF THE ARGENTINE OR "NEW ORLEANS” ANT, IRIDOMYRMEX HUMILIS MAYR.}

\section{By Wilmon Newell, Baton Rouge, La.}

It is not often that the economic entomologist is privileged to behold the coming of a new and dangerous pest, to see its numbers rapidly increasing for several years before it attracts more than casual attention from the "layman," and yet be practically powerless to avert the threatened catastrophe.

An insect problem practically unheard of by the majority of the members of this Association, is now presenting itself in the State of Louisiana, and will shortly present itself to most if not all of the southern portion of this country. It is, withal, a problem which in the writer's humble opinion will rank in magnitude alongside the problems presented by the San José scale, gypsy moth and boll weevil, but in marked contrast to these it is not likely to admit of remedial measures being as easily applied. 


\section{$2 \mathrm{BHL}$ Biodiversity Heritage Library}

Felt, Ephraim Porter. 1908. "Observations on the biology and food habits of the Cecidomyiidae." Journal of economic entomology 1(1), 18-21. https://doi.org/10.1093/jee/1.1.18.

View This Item Online: https://www.biodiversitylibrary.org/item/37189

DOI: https://doi.org/10.1093/jee/1.1.18

Permalink: https://www.biodiversitylibrary.org/partpdf/325761

\section{Holding Institution}

New York Botanical Garden, LuEsther T. Mertz Library

\section{Sponsored by}

The LuEsther T Mertz Library, the New York Botanical Garden

\section{Copyright \& Reuse}

Copyright Status: NOT_IN_COPYRIGHT

This document was created from content at the Biodiversity Heritage Library, the world's largest open access digital library for biodiversity literature and archives. Visit BHL at https://www.biodiversitylibrary.org. 